\title{
The Study of Indisch Architecture Development as an Effort in Preserving the Heritage of Colonial History in Medan
}

\author{
Imam Faisal Pane ${ }^{1}$, Hajar Suwantoro ${ }^{2}$ \\ ${ }^{1}$ Department of Architecture, Faculty of Engineering, Universitas Sumatera Utara, Indonesia \\ ${ }^{2}$ Laboratory History, Theory, and Criticism of Architecture,Department of Architecture, Universitas Sumatera \\ Utara, Medan, Indonesia. \\ imam.faisal@usu.ac.id
}

\begin{abstract}
The development of this nation's history does not separate from the development of colonial architecture. It is necessary for fundamental knowledge so that the understanding of the development of architecture can be part of the nation's history that is important to be studied. One of the important things from architectural development in Indonesia is the coming of Dutch influence. The term of Indisch is used to refer to the developing architecture in the colonial area. The development of this architecture extends mainly at major cities in Indonesia including Medan City. This paper describes the development of Indisch architecture in Medan City and the efforts to maintain and preserve it. The method used is a descriptive qualitative approach in order to describe the facts that exist in the field and to study it by the theory used. The result shows that the development of architecture does not separate from the development of the city in the colonial period. By growing of city development during the colonial era, so the building is an important element in it. The conservation effort is an attempt to maintain the existing history and memory.
\end{abstract}

Keywords: Colonial architecture; indisch architecture; history.

\section{Introduction}

Historical development cannot be separated from the development of architecture. As we know our nation has experienced a long-period colonialism. Some countries have ever come and colonized this country and the Netherlands is the longest-running country in Indonesia. Colonial power has an impact on the social conditions of the community and the identity of the local community (Jessup, 1985). Power was started by traders who monopolized trade in the archipelago until finally taken over by the Dutch government. Various incidents of rejection occurred against colonialism and with all struggle finally this nation was able to be independent and recognized by other countries in the world.

Although the colonial period was so long, the role of history could not be reversed. Some of these good and bad historical events have been traversed by this nation, one of which is about the development of architecture and the development of big cities in Indonesia. City development in the early 1800s began to occur as a result of the widespread trade carried out by the Dutch East Indies government with other countries in the world. One of the developing cities is Medan and its surroundings, as a city in the western part of Indonesia and has a variety of potential natural resources. With the flow of business carried out by the colonial government, it is automatically necessary to expand the city area by building new facilities to support trading movements, for example the Kesawan area (Sinar, 2011).

The development of architecture in this colony is often determined by policies that occurred at that time. In addition, the wave of architects working for colonial government has increased, of course this has an impact on the development of its architecture. Rapid development led the colonial government to differentiate the development of architecture in the Netherlands from the colonies. The term used by the colonial government in mentioning its colonial area was Nederlansch Indisch or Dutch East Indies. In the architecture, this term was adopted as Indisch Architecture. This term is also known as the Indische Empire (Handinoto, 1994). During the reign of the Dutch East Indies under General GovernorHerman Willem Daendles (1808-1811) had a major influence on the city of Batavia (Jakarta) and several other cities in Java. The influence which was brought by Daendles was widely 
applied to buildings built during his reign. At that time the style that developed was the Indischche Empire which took the Empire style from France (Handinoto, 2008).

Then the term Indisch Architecture began to be used and it was in line with the development of architecture in major cities in Indonesia which was colored by a very strong influence from the development of architecture in the Netherlands at that time. Climate factors are factors that must be considered in the development of this architecture. Fromsome colonial buildings that can still be used today, the role of climate is seen in the planning of the building. For this reason, the existence of a building that still functions well so that it can be preserved for the sake of the history of the development on this nation.

The history of the development of Indisch architecture is part of the historical development of this nation. What happened in the colonial period can be seen by the existence of one proof that is in the form of colonial heritage buildings. In the development of cities, colonial heritage buildings became part of city planning. Its existence must be a priority because it has memory and cannot be separated or ignored (Ginting et al, 2015). Knowledge about colonial architecture in general and Indisch architecture specifically needed for understanding the importance of the past. One example of Indisch architectures in the colonial period was the Ria cinema building Medan (Figure 1.)

In relation to this understanding of Indisch architecture, the most basic thing is how to strive for its preservation so that everything which is still there can be well maintained. It is needed to explore colonial history, this history is mapped to the development of its architecture, because in its development, there is a continuous process that looks like it is today.

Indisch Architecture began to develop in the $18^{\text {th }}$ to $19^{\text {th }}$ centuries. At that time, Indonesia was still under European colonialization. The colonial government which had the most influence on Indonesia was the Netherlands (Pawitro, 2015). In the early $18^{\text {th }}$ century, several parts of Indonesia were occupied by Dutch trading companies (VOC) with their center in Batavia. The influence of Dutch culture is reflected in government buildings which scattered on the island of Java, such as in Madiun (Sukarno et al, 2014) and Kediri (Fajarwati et al., 2011). However, on the island of Sumatra, especially on the East coast, the influence of Dutch arrivals has not been seen as significant (Anderson, 1823). The civilization of society at that time was still very pure and Malay buildings were still used with their original identity. The community governance system was also still managed customarily with the Sultan's authority at several points such as Siak, Deli, Serdang, and Langkat. During that period, there was no acculturation between the Malay local culture and European culture in the eastern coast of Sumatra. Local people already knew a new civilization, but there were also primitive ones. Dutch trading companies had not occupied the East coast region (1822 - 1823) and the plantations had not yet been opened. Malay people still enjoy freedom on their own land with a decent life and have not been disturbed by the presence of the VOC which will later monopolize the trade of agricultural products to the east coast of Sumatra.

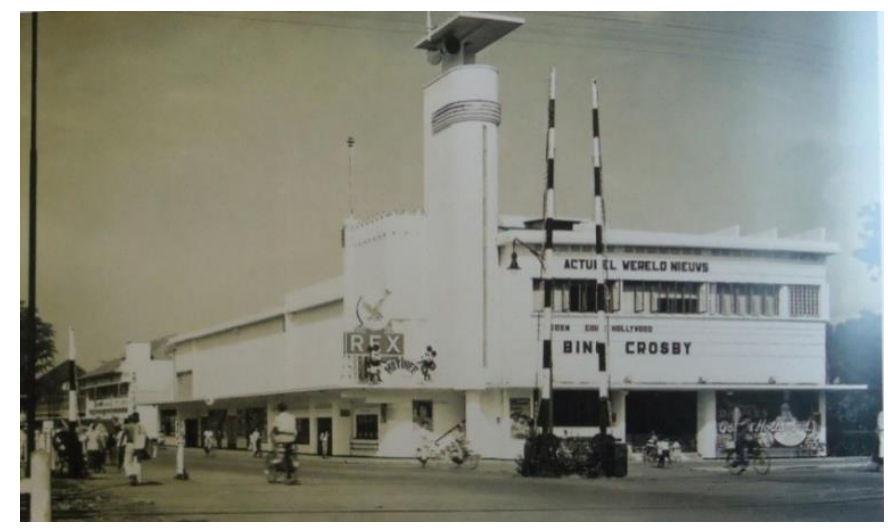


The method used to see the existence of Indisch architecture, by looking at the facts in the field, this research uses descriptive qualitative method. (Sugiyono, 2009). This method is considered effective because the facts contained in the field are assessed by an inductive approach (Moleong, 2000). Inductive analysis is used by gathering the facts in the form of literature and field data from several colonial buildings in Medan.

Descriptive approach is used so that the followed explanation according to the direction of the development of this architecture. The things that are considered necessary to be appointed and contribute directly to this research will be the main capital in conducting research such as architectural relations with modern architectural developments at that time in mainland Europe, especially the Netherlands. The stages of the study are divided into 3 (three), namely: 1. Data Collection, this stage is the preparation stage and the survey stage by directly seeing the architectural objects. Primary and secondary data collection are used to collect relevant data including the literature used for this study. 2. Data Compilation, in this data compilation stage the data has been compiled and sorted from the data that has been obtained and grouped to validate the data in accordance with existing historical facts. 3. Data Analysis and Drawing Conclusion are the most important stage in this study because the theory used in the study with case studies in research is studied, namely colonial buildings in Medan. After the analysis phase, conclusions and recommendations will be drawn which are useful for the development of science in the field of architecture.

\section{Discussions}

Indisch architecture politically by the Dutch is intended to be a differentiator from the previously developed (traditional) architecture. The development of this architecture was supported by regulations issued by the colonial government at that time and in its implementation must be obeyed. Decentralization policy has had a broad impact on urban development and architecture at that time.

The development of Indisch Architecture in Indonesia is generally divided into 3 (three) periods of development, namely: 1. The beginning period of development, 2 . The period of eclecticism influence, 3. The period of functionalism influenceand international style. From a series of buildings in the city of Medan, these three periods of architectural development are analyzed in line with the historical development of Medan. Some colonial buildings became case studies, namely: Tip Top Restaurant, Commercial Building (Bata Shoe Shop) and Indonesian Plantation Museum.

\subsection{The beginning Period of Development}

The beginning period of Indisch architecture developmentwas marked by the development of colonies, this development was in line with the development of major cities in Indonesia. The city of Medan is a city that developed along with the plantation business that was opened by the Dutch colonial government. In the beginning of its development, Indisch Architecture is related to residential buildings called landhuiz, which are traditional house mixes with European architectural styles. The early stages of this development emphasize the tropical conditions and local cultural environment. One of his famous architectural works is the Jakarta National Archives Building, this building was once a spacious courtyard and was often referred to as heernhuizen and landhuizen (Handinoto, 1994) (Soekiman, 2014) (Figure 2.). 


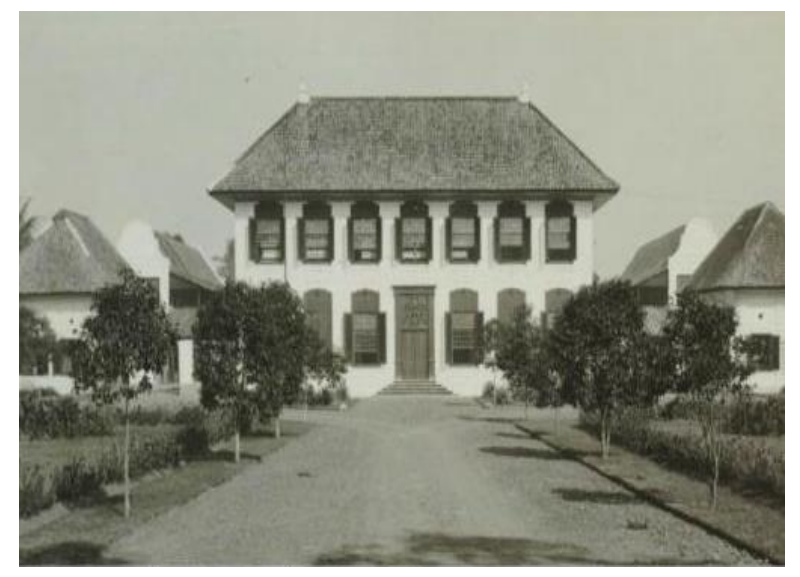

Figure 2. National Archives Building, Jakarta (source: KILTV Tropenmuseum)

\subsection{The period of Eclecticism Influence}

The Influence of Eclecticism and Functionalism plays a role in the formation of Indisch Architecture as a whole. The influences brought directly by Dutch architects were combined with local climate conditions. Indisch architecture became increasingly colorful as a result of the input of this architectural style. This influence in Indonesia began with the development of Neo Classical Architecture in the Netherlands and other European countries. This influence was significantly brought by Dutch architects who work in Indonesia.

With this strong classical influence, several buildings were designed by using this style in Medan City and several other major cities in Indonesia. Initially, this style in Indonesia was known as the "Indisch Empire Style" which refers to classical-style architecture (Handinoto, 2008). This development was quite rapid because the style which applied was very different from the beginning of the development of Indisch architecture. Examples of buildings in the Medan which have Eclectic/Neo Classic (Figure 3).

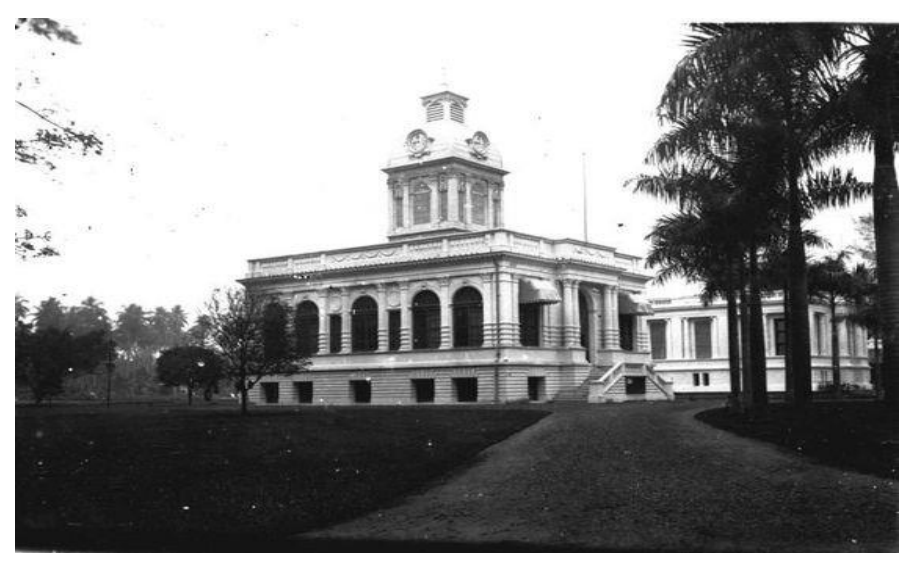

Figure 3. The Medan Mayor's Old Office

(Source: KILTV Tropenmuseum/Medan Beld van een stad, 1997) 


\subsection{The Period of Functionalism Influence and International Style}

This period was marked by a significant change in views on the culture that took place at that time. The past is no longer a reference in daily activities and a total view of the future. This loose influence from the past is related to the emergence of Avant Garde as an ideology that has broken away from the past. This influence was marked by the emergence of NiewBouwen's architectural style which was completely different from the previous style.

An architectural style that adopted the functions and forms of cubism became a trend at that time. Indisch architecture also experienced changes in the style of architecture. De Stjil's influence was very strong in the development of architecture in Indonesia, the colonial government with its policies towards the colonies made rapid development on the major cities in Indonesia. Rows of buildings with this architectural style in the city of Medan are in the Kesawan Medan area (Figure 4.).

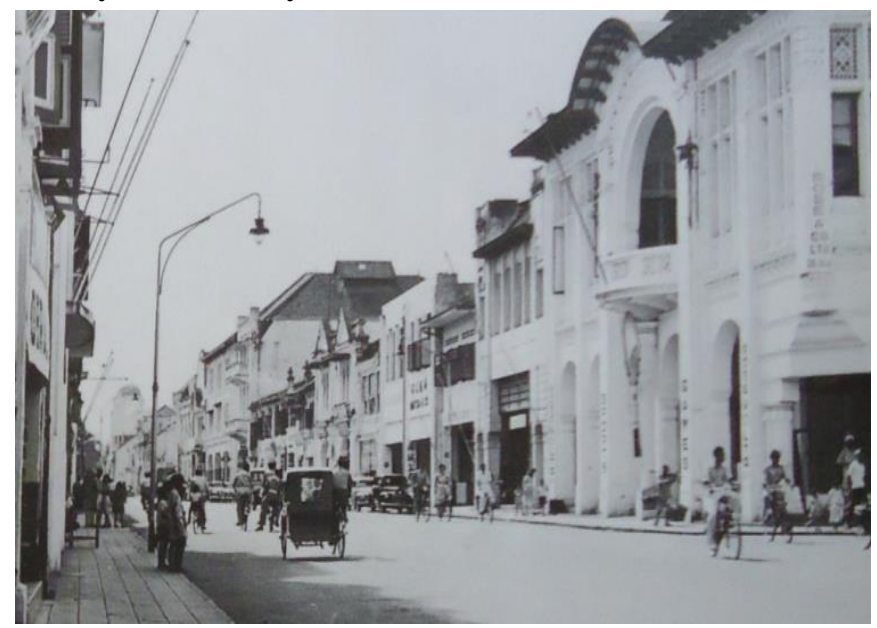

Figure 4. The situation in Kesawan which was full of colonial buildings

(Source: Medan Beld van een stad,1997)

\subsection{The influence of Indisch Architecture on Case Studies}

The influence of Eclecticism / Neo Classical happened to the development of architecture in Indonesia, especially the city of Medan. Looking at the case studies raised in the study, the analysis of these influences was traced to the dominant influence on the three case study buildings (Tip Top Restaurant, Commercial Building (Bata Shoe Store) and Indonesian Plantation Museum) (Figure 5.).
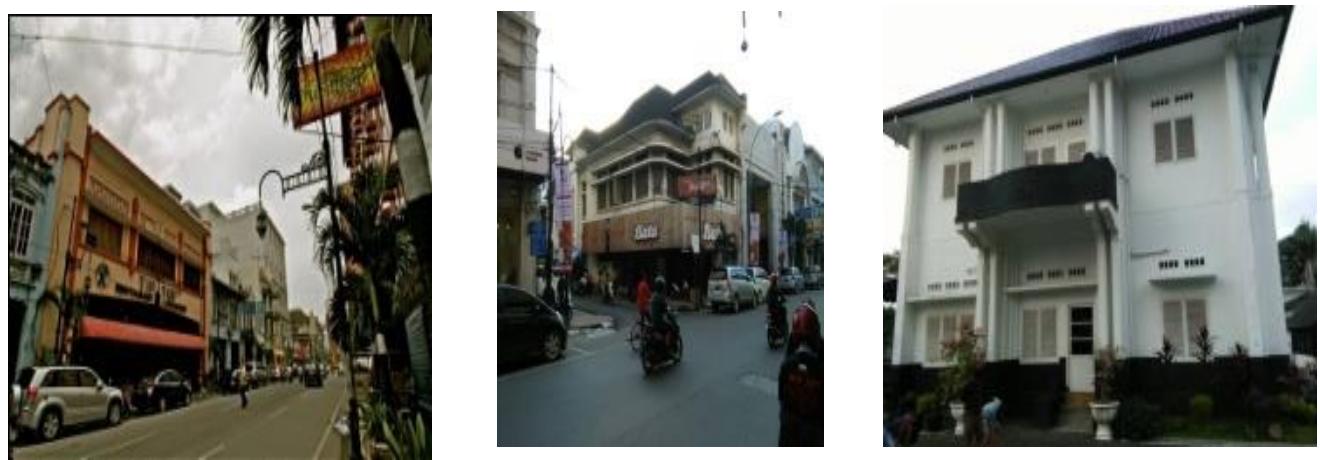

Figure 5. Tip Top Restaurants, Commercial Buildings (Bata Shoe Stores) and Indonesian Plantation Museum 


\section{A. Form and Function of Building}

The form and function of the building are different when they are in eclectic and functionalism period. In the eclectic period, buildings tend to be symmetrical with square shapes. This building refers to Greek and Roman architecture which tends to be square buildings.

In functionalism period, form of building is more various, especially the discovery of reinforced concrete technology in the early days of modernism. Functionalism and International Style indicate that buildings have various forms and do not have to be symmetrical. With the development of technology, building's form can be harmonious arrangement of geometric shapes that blend together.

From the three case study buildings it is seen that the building's form tends to be symmetrical, but in commercial buildings which locate on the corner, the form followed the street corner. In general, the eclectic influence exists but is not dominant, the building designer wants to display a monumental impression but not with a classic nuance in the building.

\section{B. Building Ornaments}

For aspects of building ornaments, during the Eclectic/Neo Classical period, classical ornaments such as Yunani with Doric order, Ionic and Corinthian and Roman with Tuscan and Composit. This typical ornament is usually found in the front facade pad's building column. Some buildings are equipped with pediment, the upper part of the column is triangular.

During Functionalism period and International Style, most buildings did not use the ornaments anymore as in the Eclecticism. The building only has horizontal and vertical lines to reinforce the shape of the building. Some air vents are used to give air come in with geometric shapes or flora.

For building ornaments, these three case study buildings do not use Greek or Roman ornaments. The three buildings are seen only using columns without ornament to reinforce the facade of the building. This ornament is also not visible in the building, the building designer is firm and ensures that this building follows the rules of Functionalism and International Style.

\section{Conclusion}

The conclusion that can be drawn from the study that has been done is the results of the searching for the development of Indisch Architecture in the city of Medan. The result is that the buildings used as the case study have the influence of Functionalism and International Style those are stronger than Eclecticism. This can be seen from the table below (Table 1.).

Table 1.Research Conclusion

\begin{tabular}{llll}
\hline No. Research Aspects & $\begin{array}{c}\text { TipTop } \\
\text { Restaurant }\end{array}$ & $\begin{array}{c}\text { Commercial } \\
\text { Building }\end{array}$ & $\begin{array}{c}\text { Plantation } \\
\text { Museum }\end{array}$ \\
\hline $\begin{array}{l}\text { Form and Function } \\
\text { of Building }\end{array}$ & $\begin{array}{l}\text { The form and } \\
\text { function of } \\
\text { building are }\end{array}$ & $\begin{array}{l}\text { The form and } \\
\text { function of } \\
\text { building are not }\end{array}$ & $\begin{array}{l}\text { The form and } \\
\text { function of building } \\
\text { are symmetrical but }\end{array}$ \\
\hline
\end{tabular}




\begin{tabular}{llll}
\hline & $\begin{array}{l}\text { symmetrical to } \\
\text { present a } \\
\text { monumental } \\
\text { impression }\end{array}$ & $\begin{array}{l}\text { symmetrical. } \\
\text { Forms tend to } \\
\text { follow the } \\
\text { position of the } \\
\text { building. }\end{array}$ & $\begin{array}{l}\text { the classic } \\
\text { impression is not } \\
\text { visible. }\end{array}$ \\
\hline 2. Building Ornaments & $\begin{array}{l}\text { Not using classic } \\
\text { ornaments, only } \\
\text { vertical and } \\
\text { horizontal lines } \\
\text { like balustrade. }\end{array}$ & $\begin{array}{l}\text { Building tend to } \\
\text { be free of } \\
\text { ornaments both } \\
\text { outside and inside } \\
\text { buildings. }\end{array}$ & $\begin{array}{l}\text { The facade only } \\
\text { bases the column } \\
\text { lines without } \\
\text { ornaments and the } \\
\text { arrangement of } \\
\text { windows in the } \\
\text { front view of the } \\
\text { building. }\end{array}$ \\
\end{tabular}

While conservation efforts are expected to be an effort for conservation and revitalization of these three buildings. In general, these buildings are well cared for but in the future it is expected to maintain the existence of these buildings. The suggestions from the results of this research is this research can be an input for the general society and academics in an effort to preserve colonial buildings.

\section{Acknowledgment}

I would like to thank the University of North Sumatra for funding the study with Number: 5338 / UN5.1.R / PPM / 2017 dated May 22, 2017 and for assistance from students of the Department of Architecture in the survey and data searching process in the field.

\section{References}

Anderson, John .1826. Mission to the East Coast of Sumatra in 1823. Harvard College Library.

Fajarwati, Anisah Nur, Antariksa, dan Suryasari, Noviani .2011. Pelestarian Bangunan Utama EksRumah Dinas Residen Kediri. Arsitektur e-Journal, 4(2), pp. 85-105.

Ginting, Nurlisa \& Wahid, Julaihi. 2015. Exploring Identity's Aspect of Continuity of Urban Heritage Tourism. Procedia-Social Behavioral Sciences 202, pp 234-241.

Handinoto. 1994. Indischche Empire, Gaya Arsitektur Tempo Doeloe Yang SekarangSudahMulaiPunah. Jurnal Dimensi Teknik Arsitektur Vol.20, pp. 1-14.

Handinoto. 2008. Daendles Dan PerkembanganArsitektur Di HindiaBelanda Abad 19.Jurnal Dimensi Teknik Arsitektur Vol.38, No.1, 43-53.

Harisdani, Devin Defriza dan Pane, Imam Faisal. 2015. Modernization And The Effect On Architecture Development (Case Study: RISPA Building, Medan). Proceedings International Conference on Architecture, Technology and Urban Infrastucture, Medan.

Jessup, Hellen. 1985. Dutch Architectural Visions of the Indonesian Tradition. Muqarnas, 3, pp. 138-161.

Moleong. Lexy J. 2000. Metoda Kajian Kualitatif. Remaja Rosdakarya. Bandung.

Pane, Imam Faisal; Suwantoro, Hajar; Zahrah, Wahyuni; Sianipar, Ribka. 2016, Architecture and Monumental (Study about form in Architecture),Prooceedings The $1^{\text {st }}$ Annual Applied Science and Engineering Conference, Bandung. 
Pawitro, Udjianto. 2015. Preservasi-Konservasi Bangunan Bersejarah dan Pengelolaan Kawasan Kota Lama. Simposium Nasional RAPI XIV FT UMS, pp. 13-20.

Sinar, T. Lukman. 2011. Sejarah Medan Tempoe Doeloe. Percetakan Perwira. Medan.

Sugiyono.2009. Metoda Penelitian Kualitatif dan Kuantitatif dan R\&D. CV. Alfabeta Bandung.

Sukarno, Pipit Gayatri, Antrariksa, dan Suryasari, Noviani. 2014. Pelestarian Bangunan Kolonial Belanda Rumah Dinas Bakorwil Kota Madiun. Arsitektur e-Journal, 7(1), pp. 39-51. 